\title{
Representations of the Japanese in Contemporary Australian Literature and Film
}

\author{
Erika Smith \\ University of Western Sydney
}

\begin{abstract}
The objective of this article is to investigate general contemporary Australian perceptions of the Japanese. I will do this by exploring how Australian contemporary literature (20062007) and Australian contemporary film (1997-2007) depicts Japanese characters. By analysing the representation of the Japanese characters in these areas I will attempt to gather a broad understanding of how Australians represent, perceive and identify the Japanese today.
\end{abstract}

\section{Keywords}

Australia, Japan, Literature, Film, World War II

\section{Introduction}

Australians have developed perceptions about Japan and the Japanese from historical, political, social and cultural experiences and relationships. These perceptions can be identified in many areas of Australian culture, including art, literature and film. Additionally, events and experiences of the twentieth century cemented feelings in many Australians that Japan was the 'other' to be most feared. ${ }^{1}$ Recently, while visiting Japan in early June 2008, Prime Minister Kevin Rudd described the Australia-Japan relationship 'in first-class working order [...] a relationship [...] based on strategic security and an economic partnership based on enduring friendship.' It will be interesting to assess whether Rudd's view of the Australia-Japan relationship is reflected in the representations of the Japanese in contemporary Australian literature and film.

\footnotetext{
1 The 'other' was used frequently in Edward Said's Orientalism (1978). Although Said's text was focused on the Middle East as the 'other' of the West, the arguments can be used in many other case studies. Said argued the 'other' was something/someone the West used to measure and compare themselves against in a positive light. Similarly, this argument of the 'other' can be understood in our analysis of Australian representations of the Japanese. Said, Orientalism

2 Coorey, 'Japan Relationship is Fine: Rudd'.
} 
.

This article acknowledges that there are very few texts that have been published on subjects related to Australian perceptions of the Japanese. Most of the analyses have been based on American textual representations. Such writers on American representations of the Japanese include Sheila K. Johnson, Narrelle Morris, Edward Said, Ross Mouer and Sugimoto Yoshio. These authors present key arguments that will be utilised in this article's analysis of Australian representations of the Japanese in contemporary literature and contemporary film. There are only two prominent authors, Alison Broinowski and Megumi Kato, who have analysed Australian specific textual representations of the Japanese.

Diplomat and academic, Alison Broinowski, author of The Yellow Lady: Australian Impressions of Asia (1992), presents a complex and deep analysis, via representations in various texts and media, of Australian perceptions of the people and countries that make up Asia. Megumi Kato's PhD thesis, Representations of Japan and Japanese People in Australian Literature (2005), is the most recent analysis of the representation of Japan and the Japanese in Australian literature. Kato's thesis examines literary representations of Japan and the Japanese from 1880 to 2005, assessing whether there is any change over a century of historical, political and social events. ${ }^{3}$

\section{Representations of the Japanese in Contemporary Australian Literature}

According to Kato, in the 60 years since WWII there has been a limited amount of literature published that represents contemporary Japanese people. ${ }^{4}$ The reality of this representation as one of friendship is challenged, particularly when the issue of WWII is discussed or mentioned. ${ }^{5}$ Similarly Dr. Ben McInnes, academic and one of the contributing writers of New Voices 1, argues, 'from this point on [post Russo-Japanese War 1904 - 1905...] literature has claimed unanimously that Australian attitudes toward Japan rapidly became negative.' Kato and McInnes are both highlighting sensitivity and the impact conflict (Russo-Japanese War and WWII) has had on the minds of Australians.

This article limits 'contemporary Australian literature' to four literary texts of different forms, written by Australians between 2006 and 2007. The four contemporary texts examined in this paper represent different genres of literature, including Barbara Fisher's poem, 'Rain and Hirohito' (2006), Mark Aird's short story, 'Sleeping Soldiers' (2006), Andrew O'Connor's novel, Tuvalu (2006) and Bryce Courtenay's novel, The

\footnotetext{
Kato, Representations of Japan and Japanese People in Australian Literature, p. 13.

Kato, 'Australian Literary Images of Japan: A Japanese Perspective', pp. 195-196.

Ibid, p. 202.

McInnes, 'Assessing Australian Attitudes to Japan in the Early Twentieth Century - A New Approach', p. 14.
} 
Persimmon Tree (2007).

Fisher's 'Rain and Hirohito' is a postmodern poem rich in imagery and metaphors. ${ }^{7}$ When analysing Fisher's poem several techniques need to be considered to understand its representation of the Japanese, including the poem's context and subject matter, imagery, style and language. The importance of context and subject is crucial in constructing meaning because of the many different themes threaded through the poem. The poem uses the past tense, reflecting on the Japanese and Japanese society at the end of Hirohito's rule $(1926-1989){ }^{8}$ 'Rain and Hirohito' represents two conflicting images of Japan, between traditional and modern Japan. Traditional Japan is represented through references to Hiroshige Ichiyūsai (1797 - 1859), a famous print artist during the Tokugawa period (1603 - 1868). ${ }^{9}$ A sense of traditional Japan is further suggested through the subject of cherry trees, and the Emperor's road..$^{10}$ In contrast, the contemporary Japanese are described going about their daily routine. ${ }^{11}$ 'Rain and Hirohito' depicts the poet's representations of the Japanese (the poem's subject) through contrasting traditional versus modern images.

The imagery of autumn, rain and cherry trees all reinforce a stereotypical romantic image of Japan, what Morris would describe as a technique to link the readers' presumed knowledge of traditional Japan to the poem. ${ }^{12}$ This romantic imagery is juxtaposed with the busy lives of modern Japanese who make 'their way to work' ${ }^{13}$ and the Emperor's declining health. The poet's view of Japan and Japanese people is made up of these disparate images,

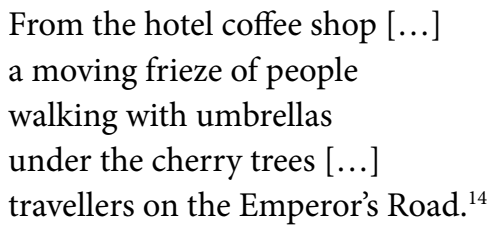

These lines illustrate an image reminiscent of Hiroshige's print series, One Hundred Famous Views of Edo. Hiroshige's print series depicts travellers along famous roads and special attractions, against the backdrop of the different seasonal weather. In some of

\footnotetext{
7 'From the 1950s and 1960s onwards, many writers addressed issues arising from civil rights movement [...] the Vietnam War (1959-1975) and other conflicts, pollution and other environmental issues, ethnic issues, women's rights and gay rights.' Wagner, Poetry Analysis 2, p. 35.

8 Bettmann/Corbis, Encyclopaedia Britannica Inc., 'Hirohito'.

The (Edo) Tokugawa period refers to the time when Tokugawa shoguns, Ieyasu, Hidetada, Iemitsu and Yoshimune ruled Japan between 1603 - 1868. Edo,

now present day Tokyo, was the capital city from the time of Tokugawa rule. Walthall, Japan a Cultural, Social and Political History, pp. 94-110.

10 Fisher, 'Rain and Hirohito', in Quadrant, p. 45, line 7.

11 Ibid, line 8.

12 Morris, "Paradigm Paranoia", pp. 53-54.

3 Fisher, op. cit., line 8.

$14 I$ Ibid, lines 3, 5, 6, 7, 10 .
} 
.

these prints, figures are seen walking, wearing triangular shaped hats that were common in the period. These hats, known as amagasa ${ }^{15}$, are then contrasted with the poet's image of modern Japan, where Japanese people are described with umbrellas, making a direct connection between the past and present through fashion.

Although 'Rain and Hirohito' has no distinct rhyme scheme, it does have a musical flow that makes its reading natural. The poem follows no traditional style, rather it consists of two stanzas of ten lines, in two columns beside one another. By separating the poem into two columns unevenly, it visually reinforces the contrasting images of past and contemporary Japan. This effectively represents the Japanese in a juxtaposition of past and contemporary, society and culture through techniques of context, subject matter, language and style.

Similar to other contemporary poems, 'Rain and Hirohito' employs straightforward, readable language. ${ }^{16}$ The language refers to Japanese traditions, stereotypes, cities, eras, history, royalty, art and culture within its twenty lines. Fisher's poem uses words, such as 'Hirohito', 'cherry trees' and 'Emperor', that Morris describes as specific words adopted and adapted in a text to function as a link between the text and the reader's knowledge. ${ }^{17}$ The poem's title and subject matter refer to Hirohito clearly. For many Australians, Hirohito draws upon the representations of the Japanese in WWII. Kato asserts the association of WWII in Australian contemporary literature demonstrates a 'lack of cultural crossings between the two countries.' ${ }^{18}$ To do so, as 'Rain and Hirohito' does, would force the contemporary Australia-Japan relationship to remain closely tied to the past.

Mark Aird's 'Sleeping Soldiers' (2006) is based on two characters, Kobayashi Keiko, and her son, Tatsuya, who is a hikikomori. ${ }^{19}$ Hikikomori is generally understood to be an individual who isolates themselves from society and family in a single room for six months or longer. ${ }^{20}$ The following paragraph is a description of hikikomori in Aird's short story, which represents a typical example of sufferers:

He would wait, and she would sleep, so he could skulk silently through the darkened house to the kitchen, just one more shadow sliding down the stairway, before returning to his room to eat. Tatsuya hadn't spoken for 10 months now, since the day he'd locked his bedroom door, separating himself

\footnotetext{
Amagasa is a direct translation to 'rain hats'.

Other poems published in 2006 include, Jan Dean's Walking to School and B. W. Shearer's The Japanese Lunch.

Morris, op. cit., p. 54.

Kato, 'Australian Literary Images of Japan', p. 202

A direct translation is 'hiding'.

'Hikikomori', Wikipedia. It must be noted that I recognise Wikipedia to be a non-academic publication of information. However, as hikikomori is a fairly

new social phenomenon there is a gap in the research and publication for me to access and refer to.
} 
from his mother and the world [...] He had his console, and the Internet to order the latest first-person shooter games. ${ }^{21}$

Hikikomori is a fairly new phenomenon and the causes are not certain, however it is believed to be linked to the pressure and stresses of the society that the victim withdraws from..$^{22}$ Hikikomori has been predominantly and popularly associated with Japanese society, even though cases have been identified in Western countries such as the United States, England and Australia. ${ }^{23}$

Contemporary Tokyo is the setting of Aird's short story, drawing emphasis to the pressure and stress associated with city life, particularly on youth. Hikikomori individuals often stay in their bedrooms, playing computer games and/or surfing the Internet. ${ }^{24}$ Often they become extremely knowledgeable and experienced with particular technology and/or games, as is exemplified in Tatsuya:

in a false world of digital enemies [...] The State's answer was the Sleeping Soldiers, lobotomised life-term prisoners; murderers and rapists, strapped in lightweight military armour, and controlled though fist-sized radio receivers jutting out the base of their skulls. Except for their assault riffles, the Soldiers never made a sound. They never disobeyed, never negotiated, never lost. ${ }^{25}$

Aird offers readers an imaginative construction of what life as a hikikomori may be like.

The Sleeping Soldiers are the State's final solution to organised crime, gang warfare, and the increasingly violent and destructive Tokyo Uni riots. ${ }^{26}$ In the perspective of the State, the Tokyo university riots are an example of the loss of their power and control of society. It is clear in the final paragraph that the Sleeping Soldiers are the hikikomori sufferers who have been recognised and recruited by the State for their 'excellence in online gaming. ${ }^{27}$ The State's solution is thereby two-fold. Firstly, to illuminate the social disruption caused by radical university students. Secondly, to deal with individual hikikomori by using them in the State's attempt to regain control. The subject of social disruption and 'the State's final solution' ${ }^{28}$ are two extremes of popular Japanese stereotypes. The Sleeping Soldiers are an example of what Mouer and Sugimoto term 'paradoxical representations' of the Japanese in Western texts:

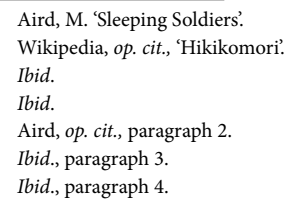


.

some of the world's greatest eccentrics are produced by the world's most group-orientated society where a supreme value is placed on conformity. One of the world's most conservative societies somehow also produces some of its most radical student groups. ${ }^{29}$

On the one hand, the social disruption is an example of the radical representation of the Japanese. ${ }^{30}$ On the other hand, the 'State's final solution' is an example of the conformist stereotype, popularly depicted in textual representations of the Japanese. ${ }^{31}$

Andrew O'Connor's 2005 Vogel Award winning novel Tuvalu (2006) focuses on the protagonist, Noah Tuttle, a 20 year old Australian man who goes to Japan to escape responsibilities and relationships in Australia. ${ }^{32}$ In Japan, Noah meets and develops a close relationship with another Australian, Matilda "Tilly" North. When Tilly returns briefly to Australia, Noah has an affair with a Japanese woman, Mami Kaketa, the daughter of a wealthy hotel owner. Once the affair is exposed, Tilly and Noah share an on and off friendship until she dies from leukaemia. Similarly, Noah and Mami share an on and off friendship. Mami Kaketa is the main Japanese character in the novel. The reader is introduced to Mami in the first chapter, 'Mami Kaketa Can Have This, ${ }^{33}$ where she appears mentally unstable, lonely and destructive.

In the first half of Tuvalu there is enough evidence presented to the reader to conclude that Mami is unstable. Especially in the chapter 'Mami Hangs Herself', when Noah describes her, 'standing on a chair completely naked with a noose around her neck. ${ }^{34}$ The representation of Mami is a long way from the archaic stereotypes in early literary texts such as those examined by writer, Karen Ma, 'many Westerners continue to believe Japanese women to be submissive servants to their men. ${ }^{35}$ This stereotypical representation of Japanese women in Western literature is also identified and analysed in the works of key writers, Johnson, Morris, Broinowski and Kato. ${ }^{36}$ Australian academic and writer, David Myers, highlights the stereotypical representation of Japanese women, with the exception of a proportion of the generations of women born during the war years, as anachronistic and no longer a correct representation of most Japanese women today. ${ }^{37}$

The descriptions of minor Japanese female characters in Tuvalu contribute to a

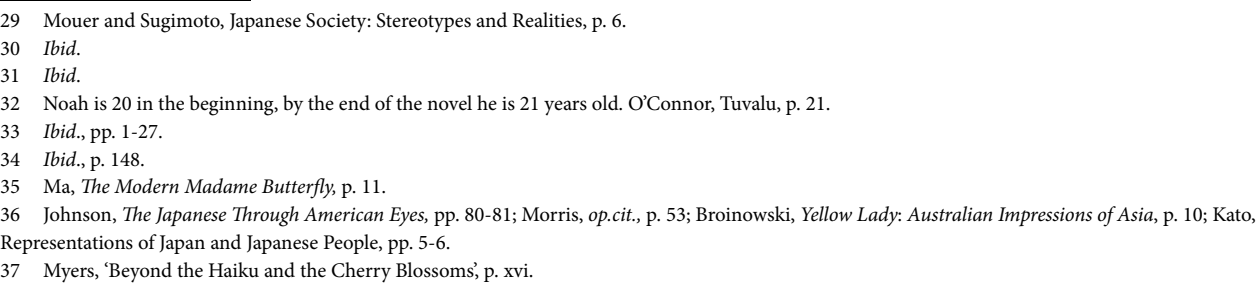


range of dislikeable character representations, as can be seen in the following excerpts:

more than a few plump, middle-aged women with fixed fuck-the-world glares. ${ }^{38}$ when we ordered a second jug of beer, an older girl came to sit with us. She proved to be sour-faced, although Harry got her to smile once or twice. She had narrow eyes which conveyed distrust and maybe contempt. ${ }^{39}$ And attractive women scowled as if they would have their looks forever. ${ }^{40}$

In Tuvalu the cherry blossom stereotype has transformed into the extreme opposite, including fierce, bitter and crazed. Both Johnson and Morris highlight this change, from the cherry blossom image of the 1970s, to the masculine, aggressive images of the 1980s and 1990s. It is not only representations of Japanese women that present the cherry blossom versus masculine and aggressive comparisons, but also general Asian female representations. ${ }^{41}$ Johnson argues that a common occurrence when representing Japanese women is the encapsulation of physicality, personality and cultural practices of Asian women. ${ }^{42}$ If both Asian-general and Japanese-specific images are confused in texts they are likely to demonstrate a reliance on hasty and contradictory stereotypes, as seen in Tuvalu.

Bryce Courtenay's novel, The Persimmon Tree (2007) follows two young lovers, Nick Duncan and Anna Van Heerdan, through their separate experiences during WWII. The novel is set between Japan, Indonesia, Papua New Guinea and Australia. However, the main focus of the novel is Indonesia, where Anna is during WWII, and Australia, where Nick is during part of WWII. Courtenay's novel demonstrates his extensive knowledge in many subjects, making it a thoroughly convincing narrative for the reader. Unlike the literary texts examined, this novel introduces and develops several key Japanese characters with more depth than those seen in Tuvalu. However, Courtenay does revert to stereotyped generalisations of the Japanese, particularly in the Japanese male characters.

The Japanese male characters demonstrate various degrees of fanatical, obsessively disciplined and sadistic behaviour. Even Colonel Konoe Akira, Commander of the Japanese Imperial Army in Tjilatjap (Indonesia), who befriends and protects Anna, is a dislikeable character. Konoe's kindness is occasionally exhibited, but easily dismissed by the reader when he verbally abuses other characters, or when the reader is reminded that 'he made sure she [Anna] understood that without his patronage she

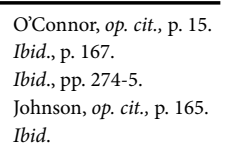


.

was in mortal danger. ${ }^{43}$ Towards the end of the War and Japan's presence in Indonesia, Colonel Takehashi, 'the executer', replaces Konoe's position in Tjilatjap. Takehashi is a far more dislikeable character, embodying sadistic, manipulative and predatory behaviour towards Anna. The only likeable Japanese male is the Radio Communication Officer and amateur artist, Gojo Mura, who is taken prisoner by Nick in Guadalcanal (Papua New Guinea). Unfortunately Gojo is only briefly included, and is the only Japanese Nick regards as, 'a very different Japanese prisoner from the blokes who blew you up. ${ }^{4}$ Despite the inclusion of Gojo, the reader is made to believe he is different from most, if not all Japanese men because there are no other representations of reasonable, humane Japanese men.

The Japanese female characters are given more dialogue and insight into their characters than those in Tuvalu. Including:

[s] even okami-san, geishas too old for active service, arrived by ship from Japan to set up two brothels. Six of them were required to work as keepers of an okiya, the Japanese name for a geisha house, running the establishments and disciplining the comfort women, while the seventh, also a retired geisha, was a woman skilled in every imaginable way of sexually pleasing a male. Her task as the supreme okami-san was to instruct the young Dutch women [...] in any sexual proclivity an officer patron might desire. ${ }^{45}$

The okami-san represent two extremely opposite female stereotypes seen so far. On the one hand they are the cherry blossom stereotype in front of men, quiet, formal and obedient. Among other women the okami-san gossip, insult the Japanese commanders in charge and openly discuss topics otherwise considered inappropriate for women, such as sex, bondage and drugs. The Persimmon Tree reiterates the same arguments presented in the previous literary analyses, that the representations of the Japanese female characters are superficial, generalised and repetitive of previous works.

In one of the first descriptions in the novel, Nick recalls his childhood in Japan and his observation of the Japanese:

it was a source of constant bewilderment to me that the Japanese children with whom I'd spent my early childhood and who had seldom quarrelled and never fought, had grown into adults capable of the most unmitigated cruelty, whereas adult Australians, taken overall, are a fairly peaceable and friendly bunch. ${ }^{46}$

\footnotetext{
Courtenay, The Persimmon Tree, p. 393.

Ibid., p. 583.

Ibid., p. 394

6 Ibid., p. 89.
} 
One only has to examine Australian history and the treatment of the Indigenous people to realise that Nick's understanding of cruelty is ignorant. Nevertheless, the image of the Japanese in WWII is frequently negative, often drawing on sadistic, cruel and fanatical behaviour. This generalised representation of the Japanese is not new in literature or mainstream perceptions of some Australians during WWII. On the one hand it is important for contemporary literature to acknowledge these representations, even if they may be hasty or inaccurate, to offer readers insight into mainstream perceptions of the time. However, it is equally important for texts to develop these representations in a contemporary context. Interestingly, as the most recent literary publication in this article, The Persimmon Tree is set over sixty years ago. This novel, as well as Fisher's poem, Rain and Hirohito, demonstrates a strong link between contemporary Australian writers and the experiences and impressions of the Japanese in WWII.

Up to now this chapter has offered an examination of four highly relevant examples of Australian literature published in 2006 and 2007. It is evident that WWII still has a prominent effect on writers, as seen in Rain and Hirohito and The Persimmon Tree. Kato described Australian literature to be symptomatic of stereotypes in its representations of the Japanese. ${ }^{47}$ Similarly the contemporary literature discussed in this paper has revealed stereotyped representations of the Japanese. These stereotypes include the representation of the Japanese as conformist, seen in Rain and Hirohito, Sleeping Soldiers and Tuvalu, and sadistic in The Persimmon Tree. Another dominant stereotype in Tuvalu and The Persimmon Tree was the over-stereotyped Japanese male and female characters. It will be interesting to see how contemporary Australian films represent the Japanese in comparison to the representations explored in contemporary Australian literature and whether there is a reiteration of stereotypes seen so far or a noticeable break away from stereotypical Japanese representations.

\section{Representations of the Japanese in Contemporary Australian Film}

Films, like literary texts, have mainstream popularity in Australian culture and entertainment. Therefore films, like literary texts, have the potential to be powerful and influential over the viewer's imagination, beliefs and understanding of the world. There are only a handful of contemporary Australian films that represent the Japanese. So far there has been little to no analysis of each film's representation of the Japanese. Broinowski argues that the Australian film industry has a history of perpetrating and investing fears of Asian countries, including Japan. ${ }^{48}$ The term 'contemporary' in this paper is restricted to the analysis of four motion pictures within the last decade, from

\footnotetext{
Kato, Representations of Japan and Japanese People in Australian Literature, p. 13.
}

48 See Raymond Longford's film Australia Calls, 1913; Broinowski, op. cit., pp. 18-19. 
1997 to 2006. Additionally, the criteria of the films analysed in this paper include those that are directed, produced and/or written by Australian/s within the scope of the last nine years. The films analysed include Heaven's Burning (1997), The Goddess of 1967 (2000), Japanese Story (2003) and Kokoda (2006).

There are other forms of Australian visual media that are worthy of study, including documentaries, such as those by Soalrun Hoaas ${ }^{49}$, and mini-series', such as John Doyle's Changi (2001). However, these forms go beyond the scope of this paper and will therefore be excluded. In addition, this paper will exclude Bondi Tsunami (2005), written and directed by Rachel Lucas. Bondi Tsunami is an unconventional, new style of cinematography, promoted as a 'music video motion picture [...to be viewed as a] multiplatform viewing piece [...in a] dream-like escapist way. ${ }^{50}$ It does not structure itself on a linear plot; instead it utilises and relies on sensory elements such as music, lighting, camera techniques and visual effects. It is precisely this new style of creativity and challenge to traditional cinematic conventions that positions Bondi Tsunami beyond the scope of this paper.

Heaven's Burning, directed by Craig Lahiff, is a film based on a Japanese couple Midori (Kudoh Youki) and Yukiyo (Isomura Kenji) who are on their honeymoon in Sydney. Minor characters in the film offer extreme, but nevertheless common representations of the Japanese, including racial inferiority, ${ }^{51}$ role in modern history (as an invading force) ) $^{52}$ and the perpetrators of atrocities committed during WWII. ${ }^{53}$ The minor characters function to remind the major characters and viewers of broader Australian perceptions of the Japanese as the 'other'. Nevertheless, the film's representation of the Japanese is predominantly developed through the two main Japanese characters, Midori and Yukiyo. Midori and Yukiyo are introduced as typically boring and conservative, the 1980s and 1990s stereotypes of Japanese people (0:02:51). ${ }^{54}$

Determined to find a more independent and liberated life, Midori fakes her own kidnapping and then accidentally becomes the hostage in a failed bank robbery involving Colin (Russell Crowe). Shortly after the failed bank robbery, Midori and Colin team up as a criminal couple. When Colin asks Midori if she wants to go back to Japan, Midori responds, 'many people in Japan, they have no true life. Everybody has dream but they skip dream [...] because they raised in a certain way. ${ }^{55}$

\footnotetext{
Soalrun Hoaas has written and directed several documentaries representing the Japanese in Australia. 
Midori's response presents to the viewer a representation of the Japanese as not really living because they are forced to conform to unhappy and essentially inhuman lives. This stereotype is later reiterated when Midori has her hair cut and dyed, and stands with her head out of the car sunroof screaming, 'I can breathe. I can breathe' $(0: 37: 30) .{ }^{56}$ This memorable scene represents once again the film's portrayal of the Japanese in their conformist society, unable to act upon dreams and therefore not really living, reiterating the stereotype Mouer and Sugimoto's work recognises. ${ }^{57}$

Toward the middle of Heaven's Burning both Midori and Yukiyo have their hairstyles changed dramatically $(0: 40: 38) .{ }^{58}$ When Yukiyo shaves all his hair off, the background music features a shakuhachi, ${ }^{59}$ evoking traditional Japanese samurai culture. ${ }^{60}$ The film's incorporation of samurai tradition is a technique recognised earlier in the previous section. Morris argues that this technique, 'successfully invoke[s] and naturalise [s] for the reader a connection between the work and the subject matter of the work.' ${ }^{\prime 1}$ In this case, Heaven's Burning represents contemporary Japanese with traditional Japanese samurai culture. The problem that arises from this representation is that the film avoids challenging stereotypes of the 'other' and instead, encourages them.

The Goddess of 1967, directed by Clara Law, centres on a blind woman, Deirdre (Rose Byrne), and Yoshio (Kurokawa Rikiya), a young Japanese traveller escaping authorities in Japan. This film involves a combination of contrasts, 'a fragmented feast', not only between the characters but all aspects of the film. ${ }^{62}$ The film's title is the popular name of a 1967 model Citroën car, which functions as the physical and metaphorical vessel in which three generations of abused women communicate their stories of suffering.

For Deirdre, her mother and grandmother, the Goddess provides a temporary escape from the abuse that they have experienced. For Yoshio, his obsession with the Goddess is tied with an early French film, in which the villain escaped the authorities by driving the Goddess. It becomes clear that Yoshio sees parallels between himself and the criminal in the French film, and therefore views the Goddess as the only way to successfully escape. Despite several direct visual representations of Japan as a technologically affluent country, The Goddess of 1967 does not include common representations of the Japanese in reference to WWII or stereotypically traditional

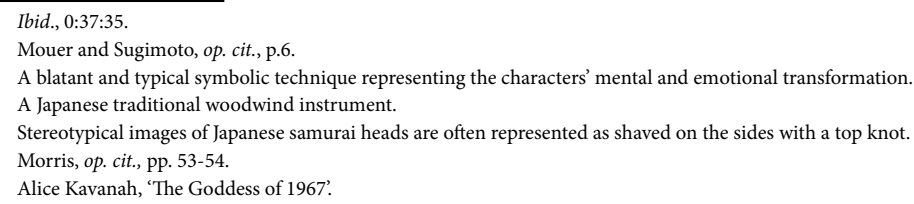


.

Japanese culture.

Modernism and postmodernism are two contrasting periods represented in the film. The Goddess represents modernism as opposed to the more contemporary period of postmodernism, reflecting the films use of contrasting elements. Modernism is represented as the past, but also in connection to Australia, whereas Japan is represented as the postmodern. Tokyo is visually represented several times in the film, in the beginning, middle (Yoshio's flashback to his past) and at the end. Each of these, besides the middle flashback, represents Japan in a blurred, blue-wash filter. The images of Tokyo are intended to represent a surreal, hi-tech, futuristic, unfriendly, machinedriven 'other-world'.

The postmodern world of Japan, according to Law, is embodied in the representation of Yoshio, 'He's the product of excessive materialism and the taking over of our life by [...] technology and big corporat [ions...] the postmodern existence is cold and inhuman and incomplete. ${ }^{63}$ Yoshio is trying to escape not only his past and commitments, but also a general dissatisfaction with Japan, the postmodernist world. When Deirdre asks Yoshio about Tokyo he responds that 'it's like living in Mars [...] you know Mars? [...] the chocolate bar. ${ }^{64}$ The film's visual and verbal descriptions of Japan emphasise an alien world - where people rarely communicate, their lives revolve around technology and anything deemed socially strange is only exhibited at home. ${ }^{65}$ The Goddess of 1967's representations of the Japanese is similar to the representations of the Japanese in Heaven's Burning, where the Japanese are unable to authentically live. This is a common Western perception of Japan and the Japanese. According to Mouer and Sugimoto's arguments, ${ }^{66}$ dominant representations of the Japanese are often inaccurately limited to single dimensional generalisations. In the case of Heaven's Burning and The Goddess of 1967 the majority of the Japanese are presented as conservative and where value is placed on conformity. ${ }^{67}$

On two occasions Yoshio can find no better way to describe himself to Deirdre other than, 'I am a man, a Japanese man. ${ }^{68}$ When we question the purpose of Yoshio being Japanese we recognise that a Japanese character adds to the film's construction of contrasting composites. The characterisation of a lead Japanese man contrasts strikingly to an Australian woman. Despite the 'otherness' that the film places on the character of Yoshio, it presents him as a trustworthy character harbouring only good intentions

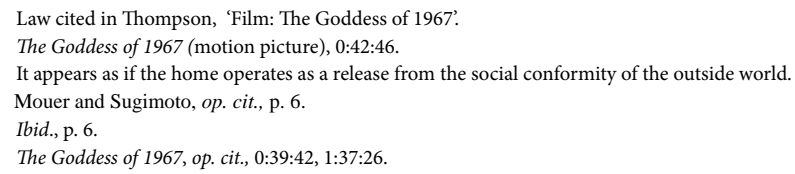


toward Deirdre. Yoshio's simple description of himself to Deirdre presents interesting self-reflexive moments, and foregrounds how race, as a subjective construction, is inadequate. This is further emphasised when Yoshio says, 'I look like a human being.' ${ }^{\text {' }}$ The film is about contrasts, but also about deconstructing the significance of these contrasts. By offering a genuine rapprochement between two of the most contrasting characters, an Australian woman and a Japanese man, the film illustrates the potential for characters from different cultures and worlds to be able to develop beyond racial constructions and cultural differences.

Japanese Story, directed by Sue Brooks is a cross-cultural physical, mental, economic and emotional exploration. This film centres on two characters, Sandy Edwards (Toni Collette) and Hiromitsu Tachibana (Tsunashima Gotaro), who are thrown together by circumstance, and within a couple of days, develop a relationship and are then separated by death. Japanese Story is packed with stereotypical representations of the Japanese, but at times challenges their construction to offer viewers insight into the broader Australian-Japanese relationship.

From the beginning, the film deliberately establishes popular stereotypical representations of the Japanese. By doing so the film creates a framework of the 'other' as a 'compendium of Japanese stereotypes' as seen in previous films. The film can either continue to reiterate these stereotypes or challenge their substance. ${ }^{70}$ When Baird (Matthew Dyktynski), Sandy's business partner, tells her she will be guiding Hiromitsu in the outback, the following exchange occurs:

[Sandy:] I'm not traipsing around the bloody desert with some Japanese prick who doesn't know his arse from his elbow and wants a glorified tour guide. I'm a geologist, not a bloody...geisha! What does he want?

[Baird:] How would I know? Sandy, he's Japanese. ${ }^{71}$

Their dialogue represents the Japanese 'other' as rude, sexist and inscrutable. According to Johnson, this is a common generalisation of Japanese and Asians, making the distinction between the two less definable, and instead encapsulated as a single group. ${ }^{72}$ Therefore, the representation of the Japanese becomes less accurate and more often than not, includes incorrect generalisations that are ultimately racist.

It is clear in the first meeting between Sandy and Hiromitsu that they both have different expectations and understandings of each other. When Sandy arrives at the

\footnotetext{
Ibid., 0:39.55.

Capp, 'Romancing the Stone: Outback Adventures of a Different Kind in Japanese Story', p. 31.

Japanese Story (motion picture), 0:06:12.

Johnson, op. cit., p. 165.
} 
.

airport to pick up Hiromitsu she opens the back passenger door expecting him to put his suitcase away. ${ }^{73}$ However, Hiromitsu simply stands there. After several seconds of stillness and staring pass, Sandy demonstrates difficulty putting his suitcase in the car. The viewer can see Hiromitsu awkwardly moving behind her, unsure whether or not he should offer his assistance $(0: 11: 34,0: 11: 34,0: 11: 38)$. This scene is particularly important in its representation of the Japanese. As drivers often do when picking up passengers from the airport, they take their suitcases. It appears reasonable then to recognise that Hiromitsu would not volunteer to put his suitcases in the car as he interprets Sandy as his driver. However, Sandy interprets Hiromitsu's attitude to be arrogance, 'the guy's a jerk, a real jerk. ${ }^{34}$ According to Kato, 'it seems intolerable for the stereotypical Westerner that the 'other' should be arrogant. ${ }^{75}$ Despite Sandy's interpretation of Hiromitsu, the camera and techniques offer the viewer insight into the 'other'. This scene clearly attempts to demonstrate how cultural misunderstandings are formed and generated by what is not seen between those who form these misunderstandings.

Film review writer, Rose Capp suggests the main actors in Japanese Story fail to convincingly represent their characters. ${ }^{76}$ Capp argues that one of the key problems of the film is its reliance on the representation of Japanese cultural differences and stereotypes, 'a series of rather prosaic observations on the subject of cultural difference. ${ }^{.77}$ In contrast to Capp's arguments, one could argue Japanese Story does not always rely on cultural differences and stereotypes, but instead recognises their presence in popular Australian perceptions and uses them as a technique of familiarity and to develop more accurate representations of the Japanese. The technique of familiarity allows the film to acknowledge the viewer's knowledge of popular stereotypical representations of the Japanese. A second technique of familiarity would be to develop insight into these representations. The film at times offers an extension to the viewers' knowledge and 'insist[s] that cultural difference can be translated and understood' in relation to the 'other'. ${ }^{78}$ It does this by taking common or popular perceptions of the Japanese, including stereotypes, and exploring them further.

The film effectively makes the point that most Australians are familiar with the bombardment of electronics and technology that are more often stereotypical representations of the Japanese. For example, when Sandy arrives home, she turns on the computer, plays her answering machine messages, opens the fridge, uses an electronic can opener, turns on the stove, uses the toaster, turns on the jug and turns

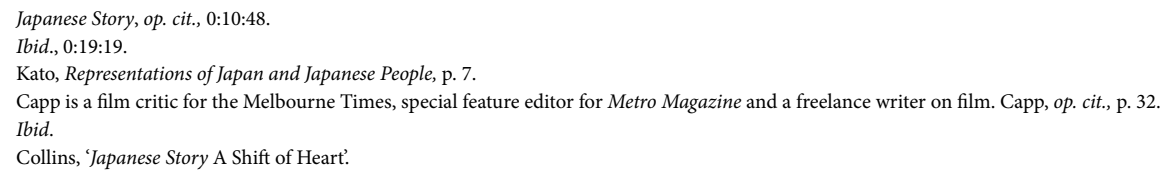


off the stove, all in less than a minute. ${ }^{79}$ On the plane to the Pilbara region Sandy is using her laptop computer, when she exits from the airport arrival gate she is on her mobile phone (0:09:18, 0:09:25) ${ }^{80}$ The emphasis on technology is popularly represented with the Japanese, as seen in the previous analysis of The Goddess of 1967. The Japanese have often been associated with the most up-to-date and sometimes useless or crazy technology. However, the technological stereotypes associated with the Japanese are no longer specifically representative of the Japanese but representative of people living in prosperous countries, including Australians. The technological emphasis on Sandy's life represents a contemporary and realistic observation of the impact technology has on the everyday Australian, not just the Japanese.

As in Heaven's Burning, it is the minor characters in Japanese Story who make references to well known WWII representations of the Japanese. The first is an offhand joke by a miner, 'don't mention the War.' ${ }^{81}$ After Sandy and Hiromitsu have sex the film explores the perceptions of WWII in more depth. An older man tells them, 'In the War we thought you blokes were coming after us, ridiculous really. Now you blokes own the place. There was a time when nobody would buy anything made in Japan. ${ }^{82}$ The comments by the minor characters demonstrate to the viewer a realistic contemporary context of the impact of WWII on Australian representations of the Japanese. The film draws upon Australian memories of WWII to familiarise, but demonstrate how little these memories represent the Japanese today. It does this by developing a relationship between Sandy and Hiromitsu.

Despite an attempt to develop representations of the Japanese from well-known stereotypes, the film fails to effectively offer new, relevant representations of the Japanese. Other examples of the film's reliance on stereotypes can be seen in the characterisation of Hiromitsu's wife. Her mask-like characterisation is reinforced in her silence and lack of emotion. Additionally, the solo playing shamisen is introduced almost every time a Japanese character is in a scene. The shamisen, like the shakuhachi in Heaven's Burning acts as a reinforcement of Japanese-ness. Perhaps Japanese Story sought to produce another film that lacks new vision into the Japanese beyond reiterated stereotypes to achieve popularity with a mainstream Australian audience.

Kokoda (2006) directed by Alister Grierson, is the most recent film demonstrating Australian representations of the Japanese. Based loosely on some of the events of the Kokoda Track Campaign in 1942 during WWII, the film focuses on the experiences

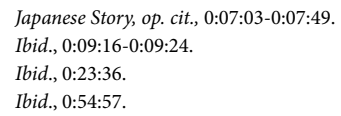


of approximately ten soldiers from the $39^{\text {th }}$ Battalion Australian Infantry 'chocos, ${ }^{83}$ intended to 'get to the heart of the meaning of Kokoda. ${ }^{84}$ The film opens with the voiceover of the protagonist, Jack (Jack Finsterer), 'the relentless Japanese war machine rolls down through South-East Asia like a deadly virus. ${ }^{85}$ Already the film positions its representation of the Japanese as a 'deadly virus', the inhuman 'other. ${ }^{86}$

A fascinating aspect of Kokoda's representations of the Japanese is the nonexistent faces of the Japanese soldiers, adding to the film's representation of the Japanese as inhuman. They are always shown as slightly blurred, covered with jungle foliage or removed from the camera shot (0:27:43, 1:15:56, 1:09:55). ${ }^{87}$ American academic and historian John W. Dower argued in 1986 that during WWII the Japanese were represented as animals, a technique of distinctly separating 'them' (Japan) from 'us' (America) ${ }^{88}$ Kokoda employs the technique of 'othering', this time representing the Japanese as alien and the Australians as human battlers. In the 'Director's Commentary', Grierson identifies a scene between a Japanese soldier and Australian soldier as 'the alien scene' (0:27:43). ${ }^{89}$ By representing the Japanese as alien, the film is reinforcing the popular stereotype of the Japanese as the inhuman 'other'.

Unlike the rugged, hungry looking, tattered and unshaven Australians, the Japanese are cleanly dressed, athletic and always appear advantaged over the chocos. The camera focuses on shoes and feet to highlight the difference between the Australians and the Japanese. The camera usually films the Japanese from the knees down, drawing attention to the Japanese soldiers' shoes, which resemble brand new scuba diver-like, rubber soled shoes. In contrast, the Australians are filmed picking dead skin off their feet, walking through deep mud, wading chest-deep in water and occasionally showing extreme wear or damage to their shoes (1:16:36, 0:03:41, 0:03:16, 0:13:35, 1:04:03, 0:52:51). In contrast, the feet of the Japanese are represented only on dry land, impeccably clean, comfortable and with a brand new appearance (0:26:28). The comparison of the feet and shoes worn by Australian soldiers in contrast to the Japanese is intended to present the Australians as the more disadvantaged of the two, thus reinforcing the heroic Australian battler image.

In reality the film is set in a time period where the Japanese had already marched almost the entire length of the Kokoda Track..$^{90}$ According to Reg Markham,

\footnotetext{
83 Chocos is the shortened version of Chocolate Soldiers, the name given to soldiers who were not part of the Australian Imperial Forces (AIF). As they were not part of the AIF it was believed that they would melt in the heat of battle.

84 In the perspective of WWII on the Kokoda track this was only the beginning of the battle. As the film only represents three days in 1942 , there are still three more years of fighting. Maddox, (6th April 2006) 'Kokoda Revisited'.

85 Kokoda (motion picture), 0:00:44.

6 Ibid., 0:00:44.

Images of the Japanese are often filmed from the shoulders, hips or knees down, thus removing their face from the camera's view.

John W. Dower, author of War Without Mercy: Race Power and the Pacific War, cited in Morris, op. cit., p. 49.

Kokoda, op. cit., (Director's Commentary) 0:27:55.

The Japanese had advanced almost to Port Moresby, which is close to the opposite side of Papua New Guinea from where they had started. It was the
} 
a former corporal of the Kokoda campaign, 'it was the sheer stretch of the supply lines that killed them.'91 The Japanese were equally, if not in a more disadvantaged position than the Australians. Nevertheless, the film deliberately represents the Japanese incorrectly in order to achieve a popular and positive nationalistic reception from Australian viewers.

Within the first half hour of the film, a choco hiding under a log is confronted by a Japanese soldier with a bayonet aimed between his eyes (0:27:43). Fifteen silent, still seconds pass before the Japanese soldier stabs the choco, his body convulses while he screams for a couple more seconds before dying $(0: 27: 58) .{ }^{92}$ The point of the delayed attack is designed to represent the Japanese as barbaric and sadistic. During the lengthy pause, the viewer is forced to contemplate why the Japanese soldier did not take the choco as a prisoner of war, or kill him instantly with a bullet in a less gruesome and disturbing way. This scene is designed to attach the viewer's sympathy with the Australian soldiers and cast the Japanese soldiers as the inhuman, barbaric and sadistic 'other'.

The next disturbing scene, '06: I Saw Jesus', shows a choco tied upright to a tree, repeatedly stabbed in the abdomen before being decapitated $(0: 32: 47,0: 32: 57) .{ }^{93}$ The choco is tied up resembling Jesus Christ on the cross, reinforced by the DVD section title. The appropriation of Christ on the cross seems intended to remind viewers to identify the chocos with Christianity and the suffering of Christ at the crucifixion. ${ }^{94}$ The murder takes place at night in the open jungle in front of an open fire. The sickly images of the Japanese maintain the film's representation of them as inhuman and cruel.

The film goes beyond representations of brutality by the Japanese into areas of the macabre. Neil Prescott, in a review for the Adelaide ABC, stated:

[...] one of the most interesting things about Kokoda is its director's conscious use of techniques drawn from horror films in order to endow this film with its requisite elements of tension, shock and suspense [0:22:16]..$^{95}$

Prescott is highlighting the film's use of horror film genre in presenting to 'a young audience an awareness of the complex history of Kokoda from an Australian point of view. ${ }^{36}$ An example of Kokoda employing the horror genre can be seen in the scenes that

\footnotetext{
difficulty in transporting food and ammunition that severely disadvantaged them. To represent the Japanese as clean and with new uniforms is a complete fabrication of the conditions that the Japanese actually experienced.

91 Markham cited in Maddox, op. cit., p. 1.

92 Kokoda, op. cit., 0:24:43.

93 Kokoda, op. cit., 0:32:01.

94 This is not the first film that includes references to Christianity. In Blood Oath, Tanaka, the only innocent Japanese character is constantly draped in

Christian imagery as a technique of creating sympathy for him.

95 Prescott, 'Kokoda'.

96 Ibid.
} 
.

begin in silence and then there is a sudden, high-pitched noise to emphasise the climax of danger. ${ }^{97}$ Another technique of the horror genre is evident in the click-click noises in the jungle, ${ }^{98}$ similar to those in John McTieman's film, Predator (1987).

Markham argues the film was only 'factual so far as the conditions were concerned, [...t] here's no real story in it except the terrible conditions. ${ }^{99}$ Grierson exchanges historical facts for a nationalistic agenda that can easily mislead the viewer's understanding of the Kokoda Track (in WWII) and the Japanese. Blood Oath (1991), like Kokoda, claims to be based on true stories and true events. According to Australian historian and academic, Hank Nelson, Blood Oath is a combination of fact and fiction, in which most of the characters and aspects of the trial were invented. ${ }^{100}$ Nelson suggests that proclaiming something is based on a true story or true events can often disillusion or mislead viewers. A significant problem with Blood Oath, according to Nelson, is that many Australians have no real understanding, if any, of the events in Ambon between 1941 and 1945. ${ }^{101}$ Likewise the events prior to the AIF arriving on the Kokoda Track are not well known. In general, most Australians are aware of the Kokoda Track and its significance in WWII, but the history of the chocos and their involvement has been largely excluded. This has allowed for Grierson to manipulate the facts, while claiming they are based on truth.

Prescott states that it was Grierson's intention for the film to tell an important part of Australian history to a generation that would generally be unfamiliar with it. ${ }^{102}$ However, as Clarke outlines in his review of the film, "the film claims to be "based" on a true story - that's different from telling the true story. Those looking for a history lesson will have to look elsewhere.' ${ }^{\prime 03}$ The director's focus on educating younger generations unfamiliar with the chocos and their experiences on the Kokoda Track becomes problematic when viewed in relation to his depiction of the Japanese and how they are represented. Kokoda represents only a single dimensional view of the Japanese as a group who are inhuman. There is the probability that Kokoda will misinform the current generation (and subsequent generations) to believe the film's representation of the Japanese as totally obsessed with the sadistic slaughter of the enemy (Australians), and with no other redeeming characteristics. Kokoda portrays itself as a film 'based on true events. ${ }^{104}$ This is misleading as it more accurately conveys bias for the purposes of nationalism and propaganda. ${ }^{105}$ Perhaps the revival of nationalism in Kokoda, where

\footnotetext{
7 For an understanding of the sharp high pitched sounds in Kokoda see Wes Craven's Scream (1996), or just about any horror/thriller film.

98 Interestingly these noises occur when it appears as though Japanese soldiers are nearby, evoking a sense once again that the Japanese are alien and inhuman, just as the creature in Predator was.

99 Markham cited in Maddox, op. cit., p. 3.

100 Nelson, 'Blood Oath: A Reel History', p. 429

101 Ibid.

102 Prescott, op. cit.

103 Clarke, 'Kokoda'

104 Kokoda, op. cit., trailer.

105 Kokoda was released on Anzac Day, 25 April 2006.
} 
there are no named Japanese characters, and the way the film deliberately dehumanises the Japanese, is reflective of the political atmosphere at the time of its release.

The contemporary Australian films analysed demonstrate many representations of the Japanese. Heaven's Burning adopts popular Australian representations of the Japanese as conformist and suppressed. Overall it withdraws from challenging dominant stereotypes of the Japanese 'other', instead reiterating them for mainstream entertainment purposes. The Goddess of 1967 represented Japan as an alien 'otherworld', reiterating the theme of life in Japan as conservative and conformist. Tokyo functions as a representation of the film's intention to create contrasts, specifically contrasting Tokyo with rural New South Wales, Australia. The film is an example of how Japan and the Japanese can be considered Australia's 'other'. Heaven's Burning, The Goddess of 1967 and Japanese Story all demonstrate a movement towards reaching a more balanced representation of the Japanese 'other'. However, they overwhelmingly revert to stereotypes in their representations of the Japanese. It is disappointing that the most recent film, Kokoda, represents the Japanese with the overshadowing aim of building nationalism. Arguably the most disturbing aspect of the film was its inaccurate portrayal of Japanese hardships suffered on the Kokoda Track and its representation of the Japanese as inhumane, barbaric and sadistic.

\section{Conclusion}

This analysis of Australian literary film and texts has revealed an interesting insight into how the Japanese are represented in the years post WWII.

Australian contemporary literature represents the Japanese as conformist and Japanese women in two extremes, the cherry blossom stereotype, as seen in The Persimmon Tree, or as mad, bitter and angry, as seen in Tuvalu. This representation has transferred to the opposite extreme in Tuvalu. Themes of WWII were still evident in the contemporary literature demonstrating how strongly Australians feel about WWII and their understanding and representations of the Japanese. The overall representations of the Japanese demonstrate a consistent reiteration of several well-known stereotypes.

This representation of the Japanese in contemporary Australian film is reflected in Midori's character in Heaven's Burning, in the contrasted setting between Australia and Japan of The Goddess of 1967, and the cultural differences in Japanese Story. Australian contemporary film demonstrated a gradual progression to more balanced representations of the Japanese. Disappointingly however, the most recent film, Kokoda, and its portrayal of the Japanese as sadistic, alien-like and inhuman demonstrate Australian perceptions from more than 60 years ago. 
Although each section of this article explored areas of analysis separate from one another, they do demonstrate an overlapping understanding of how Australian texts represent the Japanese from the post WWII years to the contemporary period (20062007). Particularly when one takes into account that the two most recent texts analysed, the novel The Persimmon Tree and the film Kokoda, both based on WWII, represented the Japanese largely as stereotypes. The evidence suggests there is a need for literature to break away from archetypal stereotypes and images of the Japanese, particularly from WWII, in order to strengthen the cultural, historical and social relationships between Japan and Australia. As long as these differences remain consistent with old images and stereotypes, the Australia-Japan relationship will be limited to a friendship based only on economic, diplomatic and military relations. This will encourage both countries to maintain and reiterate representations of one another as the 'other'.

\section{References}

Aird, M., 'Sleeping Soldiers'. Retrieved 7 October 2007, from http://Pandora.nla.gov.au/pan/10063/20060612-0000/www. antisf.com/stories/story04.html.

Artelino GmbH., 'Hiroshige 1797-1858'. Retrieved 1 October 2007, from http://www.artelino.com/articles/hiroshige.asp.

Bennett, B., Doyle, J., Nandan, S. (eds.), and Baker, L. (assoc. ed.), Crossing Cultures: Essays on Literature and Culture of the Asia-Pacific (Holborn, London: Skoob Books Ltd, 1996).

Bettmann/Corbis., 'Hirohito', Encyclopaedia Britannica Inc. Retrieved 14 September 2007, from http://www.britannica. com/eb/article-9040558/Hirohito.

Blood Oath (motion picture) directed by Wallace, S., starring Brown, B., Takei, G., and Crowe, R., (Village Roadshow Pictures, 1991, 108 minutes).

Bondi Tsunami (motion picture) directed by Lucas, R., starring Abe, T., Sasaki, M. and Ikeda, N. (Burlesque Productions, 2005, 90 minutes).

Broinowski, A., The Yellow Lady: Australian Impressions of Asia (Melbourne: Oxford University Press, 1996).

Capp, R., 'Romancing the Stone: Outback Adventures of a Different Kind in Japanese Story', Metro Magazine, vol. 138 (2003), pp. 28 - 32.

Changi (six-part television mini series) directed by Woods, K., written by Doyle, J., Curry, S., Ford, L. and Hayes, A., (ABC TV, 2001, 349 minutes).

Clarke, M., 'Kokoda’. Retrieved 2 June 2007, from http://www.abc.net.au/northqld/stories/s1628215.htm.

Collins, F., 'Japanese Story A Shift of Heart'. Retrieved 24 May 2007, from http://www.sensesofcinema.com/contents/03/29/ japanese_story.html.

Coorey, P., 'Japan Relationship is Fine: Rudd', Sydney Morning Herald. Retrieved 11 June 2008, from http://www.smh.com.au/news/world/japan-relationship-is-fine-rudd/2008/06/08/1212863458435.html. 
Courtenay, B., The Persimmon Tree (Camberwell: Penguin Group, 2007).

Dean, J., 'Walking to School', Southerly, vol. 66, no. 1 (2006), p. 157.

Fisher, B., 'Rain and Hirohito.' Quadrant, (June 2006), p. 45.

Heaven's Burning (motion picture) directed by Lahiff, C., starring Crowe, R. and Kudoh, Y. (The Australian Film Finance Corporation, 1997, 99 minutes).

Internet Movie Database Inc., 'Predator (1987)'. Retrieved 22 September 2007, from http://www.imdb.com/title/ tt0093773/.

Internet Movie Database Inc., 'Scream (1996)'. Retrieved 22 September 2007, from http://www.imdb.com/title/ $\mathrm{tt} 0117571 /$.

Japanese Story (motion picture) directed by Brooks, S., starring Collette, T. and Tsunashima, G. (Film Finance Corporation Australia, 2003, 106 minutes).

Johnson, S. K., The Japanese Through American Eyes (Stanford: Stanford University Press, 1988).

Kato, M., 'Australian Literary Images of Japan: A Japanese Perspective' in Bennett, B., Doyle, J., Nandan, S. (eds.), and Baker, L. (assoc. ed.), Crossing Cultures: Essays on Literature and Culture of the Asia-Pacific (Holborn, London: Skoob Books Ltd, 1996), pp. 195-196.

Kato, M., (PhD thesis) Representations of Japan and Japanese people in Australian Literature (University of New South Wales, 2005).

Kavanagh, A., 'The Goddess of 1967’. Retrieved 2 June 2007, from http://wwwmcc.murdoch.edu.au/ReadingRoom/film/ dbase/2003/goddess.htm.

Keene, D., Cho Cho San (Sydney: Currency Press in association with Playbox Theatre Company Melbourne and Company B at Belvoir Street Sydney, 1987).

Kokoda (motion picture) directed by Grierson, A., starring Finsterer, J. (Gen Productions, 2006, 92 minutes).

Ma, K., The Modern Madame Butterfly: Fantasy and Reality in Japanese Cross-Cultural Relationships (Rutland: Charles E. Tuttle Company Inc., 1996).

Maddox, G., 'Kokoda Revisited'. Retrieved 2 June 2007, from http://www.smh.com.au/news/film/kokodarevisited/2006/04/05/1143916591610.html.

McInnes, B., 'Assessing Australian Attitudes to Japan in the Early Twentieth Century - A New Approach' in Sone, Y. (ed.), New Voices 1, vol. 1, (Sydney: The Japan Foundation, 2007), pp. 13 - 22.

Morris, N., "Paradigm Paranoia: Images of Japan and the Japanese in American Popular Fiction of the Early 1990s", Japanese Studies, vol. 21, no. 1 (May 2001), pp. 45 - 59.

Mouer, R. and Sugimoto, Y., Japanese Society: Stereotypes and Realities (Melbourne: Japanese Studies Centre, 1982).

Myers, D., 'Beyond the Haiku and the Cherry Blossoms', in Ishido, K. and Myers, D. (eds.), Japanese Society Today, (Rockhampton: Central Queensland University Press, 1995), pp. xiii - xxvi. 
.n.m.n.m \&

Myers, D., Storms in a Japanese Teacup (Rockhampton: Central Queensland University Press, 1996).

Nelson, H., 'Blood Oath: A Reel History' in Australian Historical Studies, Richard, J. (ed.), vol. 24, no. 94 - 97 (April 1990 - October 1991), pp. 429 - 441.

O’Connor, A., Tuvalu (Crows Nest: Allen \& Unwin, 2006).

Prescott, N., 'Kokoda.' Retrieved 2 June 2007, from http://www.abc.net.au/adelaide/stories/s1625923.htm.

Said, E., Orientalism (New York: Vintage Books, 1979).

Shearer, B. W., 'The Japanese Lunch', Eureka Street, vol. 16, no. 15, 17 (October 2006), p. 28.

The Goddess of 1967 (motion picture) directed by Law, C., starring Byrne, R. and Kurokawa, R. (The Australian Film Finance Corporation, 2000, 118 minutes).

Thompson, P., 'Film: The Goddess of 1967'. Retrieved 2 June 2007, from http://sunday.ninemsn.com.au/sunday/film_ reviews/article_796.asp.

Wagner, P., Poetry Analysis Vol 2 (Clayton, Victoria: Learning Essentials, 2003).

Walthall, A., Japan: A Cultural, Social, Political History (New York: Houghton Mifflin Company, 2006).

Wikipedia., 'Hikikomori'. Retrieved 2 October 2007, from http://en.wikipedia.org/wiki/Hikikomori.

Wikipedia., 'Hiroshige.' Retrieved 10 October 2007, from http://en.wikipedia.org/wiki/Hiroshige. 